Etnográfica

Revista do Centro em Rede de Investigação em

Antropologia

vol. 11 (1) | 2007

Vol. 11 (1)

\title{
Itinerário de aprendizagens sobre a construção teórica do objecto saber
}

An itinerary of apprenticeship on the theoretical construction of knowledge as an object

\section{Telmo H. Caria}

\section{(2) OpenEdition}

\section{Journals}

Edição electrónica

URL: https://journals.openedition.org/etnografica/1931

DOI: 10.4000/etnografica.1931

ISSN: 2182-2891

\section{Editora}

Centro em Rede de Investigação em Antropologia

\section{Edição impressa}

Data de publição: 1 maio 2007

Paginação: 215-250

ISBN: 0873-6561; E-ISBN 2182-2891

ISSN: 0873-6561

\section{Refêrencia eletrónica}

Telmo H. Caria, «ltinerário de aprendizagens sobre a construção teórica do objecto saber», Etnográfica [Online], vol. 11 (1) | 2007, posto online no dia 26 setembro 2012, consultado o 12 fevereiro 2022. URL: http://journals.openedition.org/etnografica/1931 ; DOI: https://doi.org/10.4000/etnografica. 1931

\section{(c) (i) (2)}

Etnográfica is licensed under a Creative Commons Attribution-NonCommercial 4.0 International License. 


\title{
Itinerário de aprendizagens sobre a construção teórica do objecto saber
}

\section{Telmo H. Caria}

\begin{abstract}
A construção de objectos teóricos de investigação supõe a explicitação e a racionalização dos trajectos autobiográficos que se inscrevem na cultura profissional da investigação em ciências sociais. Estes trajectos mostram que as relações entre teoria e dados não são lineares, sendo atravessadas por conflitos cognitivos. Há, assim, uma cultura de problemas no quotidiano da prática científica que não deve ser confundida com as regras e conflitos de legitimação da produção científica. O trajecto autobiográfico descrito toma como objecto teórico central os conceitos de saber e de cultura profissional. Para o efeito, desenvolvese uma problemática teórica que começa e acaba na questão das desigualdades socioescolares e que se detém demoradamente na articulação entre as modalidades do sentido contextual do saber prático e recontextualização profissional do conhecimento.
\end{abstract}

PALAVRAS-CHAVE: sentido contextual do saber, conhecimento-informação, recontextualização profissional do conhecimento, mobilização do conhecimento, desigualdades socioescolares.

\section{INTRODUÇÃO: SOBRE O MÉTODO}

No debate social e científico sobre o lugar do conhecimento nas nossas sociedades tende-se a apresentar as teorias científicas como um produto social pré-construído sujeito a validação metodológica ou social. Uns enfatizam o seu realismo para descrever processos, dinâmicas e regularidades, tidos como objectivações inquestionáveis. Outros enfatizam as condições históricas e ideológicas da sua produção, tidas como subjectivações sempre arbitrárias. Ambos tendem a esquecer a intersubjectividade dos seus "construtores" (os investigadores sociais), enquanto actores sociais situados num campo social (subjectividade objectivada) e enquanto co-intérpretes de uma relação social que faz a tradução e a retroversão do sentido do real vivido por grupos sociais, através 
do filtro da teoria instituída nos campos científico-disciplinares das ciências sociais $^{1}$.

Mais especificamente, desenvolveu-se em Portugal nas ciências sociais um amplo consenso sobre o facto de a teoria social e a realidade social não serem dados adquiridos, nem terem um sentido em si próprios. São resultado de fenómenos sociais variados que, no quadro da construção biográfica da ciência social, podem ser reduzidos à escala de um processo sociocognitivo, ao fazer dialogar o uso plural da teoria nos campos científicos com o modo como a realidade social é observada e inquirida. Este diálogo é crítico, porque continuadamente tropeça em continuidades e descontinuidades, em confirmações e dissonâncias, entre o que se esperava interpretar e o que se encontra como real. Mesmo quando não temos um discurso que define claramente um novo problema ou que ajuda a ultrapassar/criticar um velho problema científico, temos sempre uma certa consciência prática, baseada numa razão construída na reflexão sobre a experiência da investigação, de que algo é contraditório, de que algo é dissonante do esperado pelas teorias científicas instituídas.

Esta consciência prática em muitos casos é ignorada (esquecida ou silenciada) pelo investigador social quando não encontra no discurso legítimo-científico lugar/posição para se exprimir. Deste modo, tende a ser desvalorizada pela própria comunidade científica de pertença, porque põe em evidência a fragilidade do "instituído" como problema científico legítimo. Mas no plano biográfico de um profissional reflexivo, de autoconstrução do investigador em interacção social com a(s) sua(s) comunidade(s) de pertença científica, as contradições e as dissonâncias de sentido são possíveis de, retrospectivamente, serem objectivadas (busca de uma linguagem conceptual capaz de criticar velhos problemas científicos através de um outro olhar sobre o real) e racionalizadas (reconhecimento do interesse que se tem com o conhecimento), evidenciando-se as condições sociobiográficas que permitem desenvolver a teoria social.

O propósito deste artigo é o de evidenciar o modo como as condições biográficas de construção teórica da investigação em ciências sociais se podem explicitar e racionalizar, tomando como exemplo o meu trajecto profissional dos últimos 15 anos. Assim, irei descrever o modo como fui desenvolvendo o diálogo crítico entre teoria/problemas científicos e os dados, e como ele me levou a desenvolver uma problemática centrada no conceito de saber. Referirei contradições, limitações e obstáculos em várias fases deste itinerário de aprendizagens.

Como julgo ficará claro para o leitor, o processo de construção biográfica da teoria que desenvolverei é bem mais complexo do que aquele que muitas vezes é descrito aos iniciantes das ciências sociais nas disciplinas de metodologias

1 Estas afirmações remetem para conteúdos relativos aos estudos sociais sobre a ciência. Para se perceber melhor a perspectiva em que me situo, cf. Caria (no prelo). 
de investigação dos cursos pós-graduados. Daqui se pode retirar a ideia de que este texto pode ter uma utilidade e uma pertinência didáctica e pedagógica para a educação em ciências sociais.

Para melhor compreender este relato autobiográfico importa não ignorar que ele é da autoria de um etnógrafo social, isto é, de um cultor das ciências sociais que submete o sentido da teoria social instituída ao sentido comum que os actores sociais desenvolvem quando vivem o seu quotidiano. Consigo-o, porque ao fazer observação participante relativizo o meu etnocentrismo (de pessoa e de investigador), compreendendo quanto a "realidade" tem um sentido heterogéneo que, numa acepção weberiana, permite afirmar: (1) os mesmos comportamentos observáveis têm sentidos múltiplos (tanto para mim como para outros participantes autóctones); (2) os mesmos significados partilhados têm comportamentos díspares (tanto para mim e como para outros participantes autóctones) $)^{2}$.

\section{DELIMITAR O PROBLEMA: UM PONTO DE VISTA SOBRE UM TEMA}

O tema geral que enquadra este texto é o das relações entre o sistemas de educação formal, as culturas do quotidiano e o desenvolvimento de saberes em contexto de trabalho. Penso que esta temática coincide, de um certo ponto de vista, com o que podemos entender pela intercepção entre educação, trabalho e conhecimento. Nesta intercepção, o ponto de vista que privilegio actualmente é o da análise social dos grupos profissionais que mais próximos estão da aprendizagem da ciência e que dela mais dependem para afirmarem e legitimarem o seu estatuto social. São também os grupos profissionais que, no quadro de uma divisão social do conhecimento, ocupam uma posição de intermediação entre as formas de produção científicas e os usos sociais da ciência pelos cidadãos.

Refiro-me à divisão social do trabalho no contexto de uma "sociedade da informação” (cf. Gonçalves 1993; Almeida 2003), como é vulgar hoje designar-se a actual fase de desenvolvimento capitalista nas suas relações com o conhecimento (Castells 2000; Lash 2005). Outro modo de apresentar o nosso ponto de vista sobre o tema indicado será referir que os grupos profissionais que nos interessam são aqueles que (de um modo descritivo) desenvolvem um trabalho técnico-intelectual (ou que são profissionais-técnicos): (1) trabalho intelectual por oposição a manual-executante, para enfatizar que se trata de um trabalho que na sociedade capitalista tende a escapar ou a resistir aos processos mais comuns de racionalização técnica ou burocrática do trabalho nas organizações; (2) trabalho técnico para enfatizar a ideia de estarmos centrados no uso/aplicação da ciência na acção social (Dubreuil 2000).

2 Estas afirmações remetem para conteúdos relativos à reflexão que tenho realizado sobre o método etnográfico, cf. Caria, 2003c. 
A esta delimitação descritiva junto aquilo que Basil Bernstein designa de recontextualização pedagógica do conhecimento resultante dos processos de mobilização da ciência para o campo escolar na forma de enunciados escritos. ${ }^{3}$ Inspirados em Stephen Stoer (1994), circunscrevemos, neste texto, a recontextualização ao âmbito profissional, porque relativa à mobilização da ciência e do conhecimento abstracto por profissionais-técnicos para o seu contexto de trabalho quando se debatem com a necessidade de saber lidar com o "outro" (o cidadão não profissional).

Este ponto de vista sobre a recontextualização profissional do conhecimento corresponde a uma linha de reflexões teóricas e pesquisas empíricas que começou a ser percorrida através dos escritos que publico desde 1997, directa ou indirectamente, ligado a grupos profissionais. Como veremos ao longo deste texto, esta linha de investigação desenvolve-se em três fases e tem dois fortes impulsos colectivos: ${ }^{4}$ a partir de 1999/2000 com a constituição de um seminário-equipa de investigação: ASPTI-Análise Social das Profissões em Trabalho Técnico-Intelectual; entre 2002/05 com o projecto de investigação REPROFOR, financiado pela Fundação Calouste Gulbenkian.

Acrescente-se que a investigação que esta equipa tem desenvolvido é de natureza qualitativo/etnográfica e tem tido uma abrangência disciplinar e temática alargada. Temos mobilizado conhecimentos que têm origem na sociologia e antropologia da educação, na sociologia das profissões e do trabalho, na psicologia cognitiva e cultural de inspiração fenomenológica e nos estudos sociais sobre a ciência. Ao lugar teórico de encontro destas diferentes perspectivas tenho chamado etno-sociologia do conhecimento profissional.

Este encontro teórico alargado tem sido particularmente pertinente para nós (membros do seminário-equipa ASPTI), porque estamos a investigar os grupos profissionais de que somos formadores: engenheiros de várias especialidades a trabalhar no terceiro sector (cooperativismo, associativismo, economia social, etc.), enfermeiros, educadores e professores, assistentes sociais, veterinários, consultores e peritos com várias especialidades em ciências económico-empresariais. Dizemos que este facto é particularmente pertinente, porque entendemos que os resultados de investigação acabam por ter relações próximas com a nossa acção enquanto formadores. Potencia-se, assim, um uso social e profissional da ciência com finalidades auto e hetero-reflexivas que podem

3 Por razões de extensão de texto não é possível aqui clarificar em que aspectos uso e subscrevo a abordagem de Basil Bernstein (cf. 1990; 1996) e em que aspectos me distancio dela. De um modo simplificado, diria que a análise dos processos de recontextualização do conhecimento pode ter uma natureza macro-estrutural, centrada nos processos políticos, como faz este autor, ou ter uma natureza micro-interactiva, centrada nos processos de aprendizagem (sociocognitivos), como se procura explicar neste texto.

4 Cf. http://home.utad.pt/aspti/index.html e http://home.utad.pt/ tcaria/. 
contribuir para uma acção-reflexão crítica, em que simultaneamente somos sujeitos e objectos de conhecimento.

\section{PRIMEIRA FASE DA APRENDIZAGEM: OUTRA MODALIDADE NAS DESIGUALDADES ESCOLARES}

A minha reflexão teórica sobre grupos profissionais começa no início dos anos 90 e tem origem na sociologia da educação e na experiência de formação sociológica de professores. Basicamente tinha dois tipos de questionamentos entre 1988 e 1992: (1) a procura de uma micro-sociologia, centrada nas representações sociais e nas trocas simbólicas entre actores sociais, que pudesse atenuar, ou evitar, os efeitos perversos do modo como os professores se apropriavam das teorias macro sociológicas de reprodução cultural através da escola; (2) a interrogação sobre as condições de possibilidade de apropriação das teorias sociais para as inserir nos contextos de reflexão educativo-profissional dos professores (Caria 1992a).

Estes dois tipos de questionamentos levaram-me à antropologia da educação através da abordagem de Raúl Iturra (1990a; 1990b; 1994) e à psicologia cultural de inspiração vygotskyana (Vygotsky 1987; Vygotsky e outros 1988; Rogoff 1993; Wertsch 1988). No caso da antropologia, ela permitiu-me clarificar que a minha primeira interrogação, sobre as relações entre os níveis de análise macro e micro, estava mal formulada, como veremos de seguida, face àquilo que encontrei para responder à segunda questão. ${ }^{5}$ Comecemos, portanto, por responder à segunda questão.

O conceito de mente social (cultural e racional-positiva) de Raúl Iturra permitiu clarificar, de um ponto de vista antropológico, as limitações das teorias reprodutivistas, quando circunscreviam as desigualdades escolares apenas à dimensão das relações sociais entre diversos arbitrários culturais, isto é, apenas ao plano da aquisição desigual de conhecimento e suas consequências de dominação/resistência cultural. Do ponto de vista antropológico, existe outra dimensão das desigualdades culturais na escola, relativa ao modo como esta instituição permite ou não uma aprendizagem que possibilita a procura de conhecimento para usos próprios dos actores sociais na sua vida social, ainda que o seu uso seja marginal ou periférico face à cultura legítima (cf. Bourdieu 1987; cf. Silva 1997). De facto, para Iturra, as desigualdades na escola não são só um problema de aquisição de (cultura) conhecimentos legítimos, mas sim, principalmente, de uso de ferramentas intelectuais para manipular a cultura. Trata-se de pensar que as aprendizagens dos primeiros anos de escolaridade

5 Veja-se a este propósito o debate que desenvolvi com Bonal e Rambla, no qual questionava as limitações da sociologia da educação mais convencional para tratar das relações entre educação, conhecimento e reflexividade (Caria 1999a; Bonal e Rambla 1999). 
(saber ler, escrever, contar, desenhar, etc.) constituem-se como ferramentas de manipulação da cultura, isto é, de uso de meios intelectuais que permitem ao indivíduo saber utilizar conhecimentos em geral e, portanto, saber exprimir-se de modo a poder racionalizar a sua experiência social através de instrumentos-linguagens formalizados de representação e comunicação (os sistemas simbólicos em uso numa dada cultura).

Assim, podemos interrogar-nos até que ponto a escolaridade ensina ao indivíduo que, subjacente ao conteúdo da cultura e aos seus significados contextuais, existe uma organização/forma do mesmo (que possibilita a sua reutilização posterior noutros contextos) que está para além do significado que lhe é atribuído em cada momento por via dos processos de interacção social. Bernard Lahire (1993a) vem mais tarde a conceptualizar este mesmo problema com base em contribuições disciplinares variadas, mas equivalentes às de Iturra, designando-o de relação escriptural com o saber. Acrescenta que se trata de analisar as formas sociais escriturais que permitem aprender a separar conteúdo e forma da cultura, isto é, separar o significante e o significado dos signos do conhecimento em uso na conduta social.

No modo como interpretámos a teoria iturriana sobre a escolaridade, a conceptualização de duas mentes sociais para pensar as desigualdades escolares supõe que a actividade cognitiva de aquisição de conhecimentos está imersa numa organização sociocultural que determina o modo como a cultura é adquirida face ao uso que lhe é dado no seu meio social. É justamente neste ponto que as abordagens da psicologia cultural se aproximam das antropológicas, designadamente quando estas entendem a actividade psicológica de individualização (construção da individualidade no plano psicológico) como sendo simultaneamente social e cognitiva: (1) a socialização do indivíduo numa dada cultura leva a que a sua plena integração social esteja associada à sua plena individualização; (2) quanto mais o indivíduo é reconhecido pelos pares como competente numa cultura mais capaz é de guiar outros na aprendizagem da mesma; (3) quanto mais o indivíduo é reconhecido pelos pares como competente numa cultura, mais desenvolve a capacidade de dominar e explicitar as linguagens e os instrumentos intelectuais que suportam a sua organização social e, potencialmente, mais crítico pode ser relativamente às suas origens culturais.

É esta associação entre a actividade cognitiva e a actividade social que permite designar esta perspectiva de análise das desigualdades sociais na escola como sociocognitiva. Mais especificamente, no que se refere ao conceito de mente social, poderemos afirmar que, segundo Iturra:

$\S$ a mente cultural supõe uma organização social do conhecimento que privilegia aprendizagens e valoriza conhecimentos através de processos predominantemente implícitos, afectivos, emocionais, interpressoais, informais, circunstanciais, intuitivos, tácitos, prático-orais, locais e etnocêntricos; 
$\S$ a mente racional-positiva supõe uma organização social da cultura que permite aprendizagens e valoriza conhecimentos através de processos (potencialmente relativizadores do etnocentrismo) predominantemente explícitos, impessoais, analíticos, formais, orais-escritos e gerais.

Mas para este autor (e também para a psicologia vygostkyana) existe uma prioridade na aprendizagem: não é possível aprender (diferente de ensinar e reproduzir) uma mente racional-positiva sem a articular com uma mente cultural, isto é, o geral, o racional e o analítico para o aprendiz tem que ter um significado contextual, e ele só pode ser dado se estiver associado a um singular e a um emocional, relativo a uma acção situada no mundo.

Normalmente, quem nasce e chega a um grupo social, encontra-se já com um conjunto de taxonomias com as quais convive [mente cultural] e que, enquanto cresce e se desenvolve, não coloca em questão: obedece e respeita e não sabe porquê. O processo educativo é, em consequência, o meio pelo qual os que já têm explicitado na sua mente [desenvolveram uma mente racional-positiva] o como e o porquê da sua experiência histórica tentam retirar os mais novos da inconsciência do seu saber, daquilo que é percebido sem que seja explícito [funcionamento quotidiano da mente cultural] (...) A questão está em saber se é mais útil para a reprodução do grupo que os novos reproduzam o saber ou que entendam a necessidade dele praticando a sua utilidade. O primeiro seria ensinar o que já se tem, subordinado à letra do que já se possui como explicação da natureza e das relações entre os homens; o segundo seria aprender o processo que dinamiza as operações pelas quais a mente humana resolve uma questão, cada vez que uma problemática se lhe coloca. (Idem 1994: 30.)

Em síntese, a individualização não se opõe à socialização, porque uma plena autonomia pessoal no uso das linguagens e instrumentos de uma cultura implica a plena integração social nessa cultura particular e a possibilidade de desenvolver, caso seja um trânsfuga cultural (Vieira 1999), algum relativismo cultural com as suas origens e contextos de aprendizagem anteriores.

Relativamente aos aspectos mais restritos da escolaridade, trata-se de saber até que ponto a mente racional-positiva, que permite o acesso à cultura como instrumento-linguagem intelectual na actividade escolar está (foi aprendida) em associação com a mente cultural, originada na socialização primária dos indivíduos. Dito noutros termos, trata-se de saber se a escolaridade teve o impacto suficiente para que os conhecimentos legítimos adquiridos possam ser usados como meio social para comparar, reflectir e formalizar as culturas do quotidiano (incluindo a cultura de origem extra-escolar dos indivíduos) ou, se 
pelo contrário, o conhecimento legítimo permanece apenas associado às tarefas e contextos estritamente escolares ou afins.

Em consequência desta reformulação do problema das desigualdades socioescolares, pude neste período do meu trajecto profissional perceber que a questão do uso das teorias sociais pelos professores na sua acção profissional (que referi no início desta secção) dependia do modo como poderíamos descrever as mentes sociais dos professores quando analisamos a sua cultura profissional. E este objecto era, simultaneamente, conteúdo e forma de conhecer, micro e macro-social, apresentando configurações que dependiam das modalidades de articulação das mentes sociais e não (como pressupunha a primeira questão, que referi no início desta secção) apenas dependente da análise do conteúdo representacional das trocas simbólicas em uso nos processos micro-sociais que decorriam entre professores. Havia, assim, uma contradição entre uma resposta que se encontrava para uma pergunta e os pressupostos de uma outra.

Mas também havia um problema em aberto. Repare-se que, para a análise da recontextualização profissional, pressupõe-se o uso de teorias sociais, já constituídas socialmente, que são inerentes à definição social da categoria social "professor" de que partimos. Assim, a análise da cultura profissional dos professores implica um uso do conhecimento que é enquadrado por duas mentes sociais já constituídas, porque foram aprendidas ao longo de uma socialização escolar prolongada inerente à condição de professor. E isso é sensivelmente diferente do problema sociológico da escolaridade, a saber: como se aprende a usar as duas mentes, quando elas ainda não estão constituídas (como acontece na escolaridade básica) na categoria social de "aluno"?

\section{PRIMEIRA SÍNTESE PARA DEBATE:}

\section{FORMAS DE MOBILIZAÇÃO DO CONHECIMENTO}

$\mathrm{Na}$ altura, até 1998, não consegui situar e resolver a contradição e o problema que acabei de enunciar. Tinha, no entanto, consciência prática que existia algo não resolvido, embora isso não me impedisse de progredir na construção do meu objecto de investigação, porque da reflexão sobre as desigualdades na escolaridade, que descrevi na secção anterior, ficava claro que existiam várias formas de mobilização social do conhecimento: ${ }^{6}$ (a) umas centradas na aquisição, que

6 A expressão "mobilização do conhecimento" é nova. Noutros escritos tenho preferido usar em geral a expressão "uso do conhecimento". Prefiro neste texto utilizar esta nova noção, porque penso transmite melhor a ideia de um uso de conhecimento em geral, que não deve ser confundido com um uso mais particular: o uso na acção. Assim, a simples retenção e aquisição de conhecimento escolar, sem uso na acção, devem ser consideradas como uma forma particular de uso, uma modalidade de mobilização. Como veremos mais à frente, esta ideia de que a aquisição de conhecimento não seria um(a) uso/mobilização de conhecimento está associada a uma outra ideia errada: a escola teria um ensino descontextualizado, porque não permitiria usar os conhecimentos que nela se adquirem. 
privilegiavam o conteúdo e o significado do conhecimento; (b) outras centradas no uso na acção, que podiam privilegiar a organização e a formalização do mesmo. Parecia-me que estas duas formas de mobilização deviam ser reconhecidas na sua especificidade (na sua organização em mentes sociais diferenciadas) sem que isso tivesse que nos condenar à sua separação estanque, como era típico das abordagens sociológicas tradicionais da reprodução cultural.

Hoje posso dizer que a contradição e o problema indicados não podiam ser situados e resolvidos nesse momento, porque a minha reflexão carecia de rigor conceptual quanto à análise que fazia sobre o modo como socialmente o conhecimento podia ser mobilizado. Assim, só recentemente é que formalizei uma construção tipológica que me permite ter uma visão coerente sobre como analisar a mobilização do conhecimento (Caria 2004a). Como passaremos de seguida a especificar, a construção tipológica apresentada (ver quadro 1) está polarizada no conceito de saber.

Para melhor compreender o conceito de saber, importa repetir que enfatizamos na nossa perspectiva de análise os processos de aprendizagem que decorrem do lado do uso na acção do conhecimento pelos actores sociais, e não tanto o da aquisição/conteúdo do conhecimento, como era tradicional nas abordagens sociológicas da escolaridade nos anos 70 e 80. Importará também tomar em consideração problemáticas sobre a reflexividade (Couturier 2002) e sobre os modelos de formação (Tochon 1998 [1996]), contribuições que nos permitem partir do pressuposto/hipótese de que não existe uma equivalência automática entre conhecimento adquirido e conhecimento usado na acção (a) o conhecimento adquirido pode ser retido em memória (ensinado para ser reproduzido), mas carece de recontextualização para poder ser usado na acção, principalmente se tiver apenas por referência um contexto verbal de ensino em que o aprendiz não é sujeito activo da aprendizagem; (b) o usado nem sempre é suficientemente reflectido para poder ser explicitado e formalizado ou poder ser relacionado com conhecimentos abstractos.

O quadro 1 permite comparar e definir saber dentro de dois eixos: (a) na horizontal o eixo procura-oferta de conhecimento; (b) na vertical o eixo conhecimento adquirido-usado. Também permite situá-lo relativamente a outros conceitos (informação, competência e qualificação) que, dadas as suas diversas procedências (das ciências da educação, das ciências do trabalho e das ciências cognitivas), são geralmente confundidos com ele.

7 Esta afirmação entra em contradição com as perspectivas de investigação que se desenvolvem em Portugal nas ciências da educação em torno de uma certa reinterpretação da problemática teórica do professor investigador, das quais sou crítico. Estas perspectivas têm como consequência considerar, erradamente, que a reflexividade de qualquer profissional é um automatismo resultante da experiência (particularmente quando esta é rica e diversificada) e/ou apenas dependente de obstáculos ou veículos organizacionais. 
Quadro 1

Tipologia das formas de mobilização do conhecimento

\begin{tabular}{|c|c|c|}
\hline & Conhecimento adquirido & Conhecimento usado na acção \\
\hline $\begin{array}{l}\text { Ofertas } \\
\text { de } \\
\text { conhecimento }\end{array}$ & $\begin{array}{l}\text { Informação: Conteúdos e ideias } \\
\text { gerais, impessoais, simplificados e } \\
\text { compactados, expressos em enuncia- } \\
\text { dos escritos de modo não reflexivo, } \\
\text { cumulativo e com valor efémero, sem } \\
\text { que o contexto da sua produção e } \\
\text { construção seja enunciado ou possa } \\
\text { ser descoberto (exemplo da maioria } \\
\text { dos manuais escolares e dos textos no } \\
\text { ciberespaço). }\end{array}$ & $\begin{array}{l}\text { Qualificação: conhecimento geral e } \\
\text { abstracto usado para hierarquizar a } \\
\text { cultura (conhecimento-capital) atra- } \\
\text { vés dos jogos político-ideológicos e } \\
\text { dos conflitos de legitimidade exis- } \\
\text { tentes em campos especializados } \\
\text { do social, que permitem qualificar a } \\
\text { reflexividade dos actores sociais na } \\
\text { dependência dos especialistas de cada } \\
\text { campo social. }\end{array}$ \\
\hline
\end{tabular}

Procuras Competência: conhecimento sobre o de conhecimento uso de ideias-conteúdos abstractas e gerais na resolução de problemas em contexto (metacognição a partir de conhecimentos transversais).
Saber: conhecimento situado e construído na interacção social e sobre a singularidade das situações sociais (cognição situada).

Na posição inferior direita do quadro, podemos observar que o saber distingue-se de outras formas de conhecimento, porque conjuga, simultaneamente, o seu uso e a sua procura, permitindo ao actor social desenvolver um conhecer adaptado à singularidade das situações-problema e das pessoas que interagem em concreto. Assim, inspirados na psicologia vygotskyana, diríamos que o saber é a única forma de mobilização do conhecimento que torna o actor social capaz de ser reconhecido num dado contexto de interacção como autónomo (não dependente de outros) e por isso capaz de guiar outros na aprendizagem. O saber é a forma de mobilizar conhecimento (de conhecer!) mais informalizada, intuitiva e tácita, e por isso a que mais ocorre no quotidiano de vida, podendo promover comunidades de práticas (Lave 1991 [1988]; e Lave e Chaiklin 1993). No pólo inverso do mesmo quadro (posição superior esquerda) encontramos o conceito de informação, que por definição nada tem a ver com os contextos de interacção quotidianos que usam conhecimento na acção. A informação exprime-se apenas através de enunciados escritos e, em consequência, é o modo mais formalizado e impessoal de conhecer, porque é mais permeável à acção dos agentes de dominação social. Esta permeabilidade decorre do facto de a informação se inserir facilmente nos processos de descontextualização do social, em virtude de a escrita racionalizada permitir o apagamento dos contextos de sentido que motivaram os seus autores e, em consequência, dificultar o desvendamento dos processos locais e institucionais 
de filtragem/reorganização dos conteúdos de conhecimento considerados ao nível global (Olson 2002).

Nas situações intermédias, apresentadas no quadro 1 (posições inferior esquerda e superior direita), encontramos o conceito de competência (cf. Bellier, 2003 [1999]; Perrenoud 2001; Tanguy e Ropé 1994) e o de qualificação (cf. Dubar 1998; e Terssac 1998 [1996]). Numa primeira abordagem e seguindo de perto a revisão da literatura desenvolvida por Terssac (ibidem: 224-236), poderemos dizer que os dois conceitos podem ser entendidos como prolongamentos e especificações do conceito de informação, na medida em que ambos visam:

$\S$ competência-informação-explicitar o que está implicado na acção organizacional enquanto qualidades e habilidades para realizar um trabalho num dado lugar funcional;

$\S$ qualificação-informação-dar conta de processos de avaliação das qualidades do trabalho e do sistema de valores que legitimam e hierarquizam as aprendizagens e a ordem social em contexto de trabalho.

Em geral, diríamos que o conceito de qualificação é utilizado como instrumento de análise das lutas simbólicas e de classificações que se desenvolvem entre educação e trabalho, dando conta das intercepções entre: (1) a manipulação social de títulos e diplomas obtidos na educação formal, (2) as formas de institucionalização de hierarquias de conhecimento que suportam cursos e formações instituídas, e (3) as definições de funções e postos de trabalho de acordo com lógicas e conflitos de legitimidade em vários campos sociais. Um bom exemplo de parte destas perspectivas são as análises sócio-históricas sobre as profissões (no âmbito da sociologia das profissões), nas quais se enfatiza a manipulação que socialmente diversos grupos ocupacionais fazem do conhecimento (na formação, na ciência, no trabalho, etc.) para que nos seus campos específicos de acção profissional tenham ganhos acrescidos de legitimidade e de autonomia sociais.

Pensamos que uma das formas de pensar o conceito de competência é associá-lo à aquisição de conhecimentos e ao domínio, no plano psicológico e individual, de princípios e regras de uso da informação para resolver problemas. Esta formulação é designada pela psicologia cognitiva como actividade metacognitiva, podendo também ser designada, em ciências da educação, como correspondendo a competências transversais, porque comuns e necessárias a vários contextos de acção (Perrenoud 2001; Rey 1996). ${ }^{8}$ Um bom exemplo do nosso

8 Pelo exposto parece-me que fica claro que o conceito de competência-informação não deve ser confundido com o de competência-skill-desempenho. Abordamos competência sempre na relação com educação-formação (aprendizagem) e nunca apenas como um esquema mental (skill) capaz de automaticamente gerar condutas hábeis em contextos particulares, como geralmente é tratado pela tradição anglo-saxónica em ciências cognitivas. 
conceito de competência-informação é o modo como os estudos comparados sobre os níveis de literacia têm sido operacionalizados: colocando a hipótese de os indivíduos terem, em maior ou menor grau, uma "habilidade intelectual geral" que lhes permite serem capazes de recontextualizar os princípios de organização e formalização de uma linguagem (alfabéticos, gramaticais, matemáticos, etc.) para pensarem a acção quotidiana quando usam um código escrito dessa linguagem (Benavente 1996).

A questão decisiva que me leva a colocar no quadro 1 o conceito de competência no lado da aquisição (não do uso na acção) decorre do modo como o actor social teve acesso aos princípios e regras de organização do conhecimento. De facto o desenvolvimento explícito de uma actividade metacognitiva pressupõe que o veículo preferencial de transmissão é o verbal num contexto tendencial de educação formal (onde há manipulação de informação), em que os contextos quotidianos de potencial uso do conhecimento são referidos e indicados, mas ainda não foram vividos para que o conhecimento tenha que ser usado (Tochon, 1998 [1996]: 252-254). No entanto, a actividade metacogntiva supõe existirem procuras-motivos-estratégias próprios e autónomos, por parte de cada indivíduo, para adquirir um determinado tipo de conhecimento. ${ }^{9}$

Como dissemos atrás, o interesse desta tipologia é o facto de ela permitir analisar o conhecimento nas várias modalidades de mobilização, explicitando o facto de as teorias reprodutivistas da educação analisarem as desigualdades escolares por via de uma conceptualização que sobrevaloriza não só a lógica do conteúdo mas também a da oferta do conhecimento: conteúdo informativo legítimo gera capital cultural. Sem que o tenhamos percebido na altura, a deslocação da problemática das desigualdades para a questão da articulação das mentes sociais (a visão sociocognitiva das desigualdades escolares) implicava ver a mobilização do conhecimento numa perspectiva de uso do conhecimento como forma, isto é, como meio/ferramenta de organização cognitiva para procuras cognitivas próprias e situadas: 0 saber.

9 Como mais à frente desenvolveremos na secção 6, esta não é a única forma de entender o conceito de competência. Ele pode também ser desenvolvido em sentido inverso, na dependência do conceito de saber. Aliás, o mesmo também se pode dizer do conceito de qualificação (que não iremos desenvolver), designadamente no que se refere às perspectivas de análise que se centram no conceito de organização qualificante e às que pensam a educação de adultos enquanto processo educativo de reconhecimento, ampliação e certificação de saberes sociais. Noutro trabalho fui mais radical e sugeri que o conceito de competência-saber fosse abandonado em favor do conceito anglo-saxónico de empowerment, traduzido como capacidade e capacitação social (Caria 2002a: 816; 827). 
4. SEGUNDA FASE DA APRENDIZAGEM (1): VISÃO SOCIOCOGNITIVA DA ESCOLA DEMOCRÁTICA

Entre 1993 e 1998 dei continuidade ao meu projecto de análise da cultura profissional dos professores, embora, como disse, apenas preocupado com a questão da articulação entre duas mentes sociais já constituídas e, por isso, "fugindo" ao problema das desigualdades escolares para o qual não tinha resposta. Este foi o período de tempo em que concluí o trabalho etnográfico com professores, em que defendi a minha tese de doutoramento e em que comecei a esboçar a possibilidade de "exportar" para outros grupos profissionais a problemática que tinha desenvolvido para análise do trabalho e do conhecimento dos professores.

Durante este período de tempo centrei a minha reflexão teórica em torno das questões, directamente ligadas ao trabalho de investigação para doutoramento que tinha em curso, de saber: Como se poderia separar analiticamente o conteúdo e a forma de conhecer na cultura profissional dos professores? Quais as várias modalidades em que conteúdo e forma da cultura profissional dos professores se podiam configurar?

Estas interrogações levaram-me, num primeiro momento, a questionar a afirmação, tantas vezes referida em variada bibliografia das ciências da educação, de que a escola ensina um conhecimento descontextualizado. De facto, uma leitura mais atenta do que são as desigualdades sociais na escola, inspirada nas contribuições de Perrenoud (1984; 1994) e Lahire (1993a; 1993b), revela que existe uma aprendizagem específica do escolar (e logo uma mente cultural própria) nos primeiros anos de escolaridade, que não é apenas o prolongamento das hierarquias culturais doutros campos: o capital escolar não é só um estado do capital cultural. Daí que afirmar o carácter descontextualizado da aprendizagem escolar é dizer muito pouco.

No essencial, o escolar, particularmente aquele que tem um enquadramento ideológico que exprime o desejo de democratizar a cultura, pode desenvolver pedagogias (cf. Caria 1992b) que visam uma aprendizagem que torne possível aos indivíduos saber retirar da experiência social (da cultura quotidiana) as formas, os princípios e as regras de organização do conhecimento que estão imersos nas mentes culturais e que se desenvolveram durante os processos de socialização primária dos indivíduos. A criação de uma instituição que visa retirar aquilo que pode haver de racional, positivo e analítico (que se transforma em conhecimento formal, generalizável e com valor de precisão) das culturas de interacção quotidiana é uma invenção da modernidade que se apoia no pressuposto igualitário (contra a ideologia dos dons naturais) de que todos têm um potencial de desenvolvimento psicológico equivalente, que os torna iguais aprendizes das formas culturais escolares (cf. Stoer e Magalhães, no prelo). 
É esta invenção social que permite afirmar, apenas na aparência, que o ensino escolar é descontextualizado. De facto poderá ser visto como tal dentro do pressuposto de a escola não se deter explicitamente nos contextos que permitem viver o conhecimento e usá-lo na acção quotidiana, ou seja, retirar o racional do cultural, o geral do singular e o formal do interactivo (Caria e Vale 1997). No entanto, existe um implícito cultural escolar, ou se quisermos um curriculum oculto, que limita a alguns a possibilidade de realizar o aparente desígnio escolar de democratização cultural (Perrenoud 1992; Perrenoud e Favre 1989) isto é, o desígnio de construir uma mente racional-positiva a partir de mentes culturais diversas. É a interrogação sobre a possibilidade de realizar este pressuposto ideológico da escola que, pensamos, justifica tentar analisar separadamente o conteúdo/informação do conhecimento (problema do poder sobre a oferta e uso do conhecimento) da forma de uso dos meios intelectuais disponíveis (problema da procura e uso social do conhecimento) que permitem e expressam uma autonomia no acto de conhecer.

No meu percurso de reflexão teórica, particularmente neste período de tempo, não pude entrar na discussão de saber se seria possível (ou através de que pedagogias) a escola realizar este desígnio democrático. A minha resposta pressupunha uma visão sociocognitiva da aprendizagem escolar que não se encontrava desenvolvida. Por isso o que me interessou foi apenas saber quais as alternativas de resposta que se encontravam disponíveis em termos analíticos para este assunto.

Entendi que existiam duas grandes alternativas de análise. A primeira, a alternativa sociológica de inspiração bourdiana, afirma que a pedagogia dominante, a da violência simbólica, dissimula o poder que associa conteúdos (mentes culturais) e formas de conhecer (teorias e instrumentos culturais/mente racionalpositiva). Nesta abordagem, seria a familiaridade prática com a cultura legítima (expressa num capital cultural homógeneo) que se tornaria uma vantagem para a apropriação das formas (sentido da cultura pela cultura, cultura cultivada) apenas por alguns, sem que fosse possível dissociá-la da experiência social dos grupos sociais que têm um ethos cultivado ou um à-vontade com a cultura (que desenvolve a tal familiaridade prática) (cf. Bourdieu 1979; 1987; Bourdieu e Passeron 1978). A segunda alternativa, a alternativa psicológica de inspiração piagetiana, afirma que o desenvolvimento cognitivo do indivíduo caminha inevitavelmente do concreto/contextual para o abstracto/racional, isto é, do pensamento concreto e do pensamento operatório para o pensamento formal. Através deste processo natural de desenvolvimento, qualquer conteúdo ou experiência social é potencialmente relevante para "elevar" a qualidade do pensamento (passando do concreto ao abstracto), desde que a aprendizagem se processe na idade adequada e em situações diversificadas (Inhelder e Piaget 1976).

O primeiro tipo de alternativa tem alimentado as correntes subjectivistas que questionam a natureza do conhecimento e da ciência e que tentaram pensar 
a mudança escolar. Estas tendem a defender um multiculturalismo segregacionista ou a propôr o fim da escolaridade, pois anulam a importância do acesso a um património cultural comum mínimo (ainda que assumidamente arbitrário) a todos os grupos da sociedade. Caricaturando, em geral, os pressupostos desta alternativa, poderemos fazer a afirmação (típica do léxico dos anos 70) que "as formas burguesas de pensar" são indissociáveis do "estilo de vida burguês". Inversamente, a segunda alternativa tem alimentado as correntes objectivistas de sinal contrário que, baseando-se numa ideologia dos "handicaps culturais" ou numa "ideologia das competências", tendem a afirmar a neutralidade social de toda a cultura, dada a possibilidade de superação psicológica de todos os obstáculos sociais ao desenvolvimento individual: o social seria algo que se acrescentaria ao psicológico (barreira que seria obstáculo ou potenciador do desenvolvimento) ou o psicológico seria sempre um potencial já inscrito no desenvolvimento natural de qualquer indivíduo que careceria de actualização face à diversidade social (actualizar competências individuais).

Como sair deste "diálogo de surdos" que não seja por via de uma posição intermédia e acrítica que procure conciliar o inconciliável? Não tinha resposta, mas sabia que o conhecimento usado na escola tinha que ter uma génese e uma expressão local, ainda que se pudesse apresentar nas relações sociais como se sempre tivesse sido e permanecesse universal. A minha tentativa de resposta só surgiu mais tarde e, como já referi, não é específica à questão da escolaridade. Passa, como veremos mais à frente na secção 8, por um olhar mais atento para as dimensões em que se pode desdobrar o saber profissional.

\section{SEGUNDA FASE DA APRENDIZAGEM (2): CONFIGURAÇÕES DA CULTURA PROFISSIONAL}

Como disse no final da secção 2, a minha tarefa no período que vai de 1993 a 1998 estava facilitada: os professores já tinham tido acesso a uma mente racional-positiva; a mente cultural profissional em análise não era fruto exclusivo, nem principal, de uma socialização primária. Daí que a discussão já não estava nas possibilidades e desigualdades de acesso a uma mente racional-positiva, mas antes no uso que lhe era dado face à organização social de uma mente cultural de natureza profissional. Assim, no corpo da minha tese de doutoramento (na versão original de 1997) as perguntas sobre as possibilidades de analisar o desígnio escolar de democratização do conhecimento em novos termos eram enunciadas, mas não tinham uma resposta (Caria 2000: 144-169).

Por isso concentrei a minha análise no detalhe desta cultura profissional: quais as condições sociais de possibilidade de apropriação das teorias sociais nos contextos de reflexão educativo-profissional dos professores? A resposta encontrada para esta última questão desenvolveu-se em torno de uma problemática teórica sobre os estilos de uso do conhecimento abstracto, que só começou 
a ser enunciada e formalizada em escritos de 1999 e de 2000 (Caria 1999b; 2000: 342-375).

Reportando-nos ao período de tempo em causa, basicamente as respostas encontradas através da etnografia com professores foram as de que este grupo manifestava ter acesso às duas mentes sociais e, portanto, por hipótese, utilizava-as na sua experiência social. Para o efeito, começámos por tomar como objecto de análise os instrumentos/meios autóctones que o grupo possuía para formalizar, generalizar e racionalizar a sua própria cultura. Como os meios e instrumentos culturais autóctones tinham uma grande relação de dependência com o centro do campo escolar, passou-se a tentar saber em que medida o conhecimento-informação, que tinha origem neste centro, era, ou não, recontextualizado para se inserir na cultura do quotidiano profissional, isto é, inserido na mente cultural dos professores. Globalmente, quanto ao problema central sociocognitivo da articulação entre as mentes sociais, as conclusões do trabalho foram negativas: não existia quase nenhuma articulação na cultura profissional do professor entre as mentes sociais.

Remeteu-se a explicação destas conclusões para a relação de poder que atravessava esta cultura profissional e que estava presente nos processos de socialização do grupo profissional no campo escolar. Assim, encontrámos três configurações da cultura profissional. Na primeira configuração, designada de domesticação da cultura profissional, existiam formas de uso do conhecimento em contexto que excluíam o conhecimento abstracto. Estavam associadas a posições e tomadas de posição no campo de submissão real do grupo ao centro do campo escolar e de consequente auto-exclusão da profissão das lutas simbólicas (político-ideológicas) em torno das políticas educativas e de aceitação da racionalização burocrática do desempenho profissional.

$\mathrm{Na}$ segunda configuração, designada de escolarização da cultura profissional, existiam formas de uso do conhecimento que mobilizavam informação, mas não o chegavam a articular com o contexto profissional. Estavam associadas a posições e tomadas de posição que eram de submissão formal do grupo ao centro do campo escolar e de relativa ambiguidade face aos jogos políticos, oscilando entre uma posição crítico-retórica sobre as políticas e um praticismo de resistência local, que cultivava acriticamente a tradição do grupo.

$\mathrm{Na}$ terceira configuração, designada de racionalização mitigada da cultura profissional ou cultura periférica da profissão, existiam formas de uso do conhecimento que mobilizavam conhecimento abstracto para os contextos de trabalho individuais do professor, e não colectivos, chegando a encontrar-se formas embrionárias de articulação com o quotidiano profissional. Mas estas tentativas de recontextualização eram limitadas por posições e tomadas de posição no campo escolar que continuavam a excluir a profissão dos jogos simbólicos do campo, procuravam critérios e prioridades para outras legitimidades no espaço social local, fora de uma relação com o centro do campo escolar. 
Complementarmente, o olhar etnográfico sobre os usos contextuais do conhecimento-informação permitiu detectar dois tipos de subconhecimentos: o técnico-estratégico (ou só estratégico) e o interpretativo-justificativo (ou interpretativo-legitimador):

1) os subconhecimentos interpretativo-justificativos, que se exprimiam através de enunciados verbais e explícitos, capazes de interpretar e/ou explicar as situações-problema a partir do conhecimento de regularidades (estatísticas, funcionais, estruturais ou sistémicas) e de dar legitimidade à actividade do grupo profissional, qualificando-o e distinguindo-o dos enunciados verbais expressos por não profissionais;

2) os subconhecimentos técnico-estratégicos, que se exprimiam na identificação de segmentos da acção profissional que permitem opções variadas no uso de recursos, isto é, permitem identificar escolhas de caminhos alternativos por referência a valores e, portanto, competências específicas para manipular objectos, tecnologias e recursos de carácter geral que possam melhorar a satisfação com os resultados obtidos.

\section{SEGUNDA SÍNTESE PARA DEBATE: ESTILOS DE USO DO CONHECIMENTO}

Como viemos a perceber mais tarde, a nossa conclusão era limitada não pelas evidências empíricas em si mesmas, mas, principalmente, porque tínhamos em grande parte sobrevalorizado a análise ao uso do conhecimento abstracto, com base na hipótese de que o essencial do trabalho destes grupos profissionais seria mobilizar, reorganizar e actualizar em novos contextos o conhecimento-informação que tinham obtido na sua educação formal prolongada (cf. Dubet 1996 [1994]; Barbier 1998 [1996]: 1-17). No caso, tratava-se de retomar a ideia de uma recontextualização profissional do conhecimento que se inspirava e se limitava, como já dissemos na secção 1 , às propostas de Basil Bernstein sobre a recontextualização dos discursos-textos em educação.

Apesar desta limitação analítica, o conjunto das conclusões sobre o meu trabalho etnográfico com professores pôde ser sistematizado numa tipologia, que designei de estilos de uso do conhecimento. Ela só foi plenamente desenvolvida no âmbito da discussão sobre o uso do conhecimento noutros grupos profissionais (Caria 2002a; 2004a). O quadro 2 dá conta do conjunto dos estilos identificados, relacionando-os com as formas de uso da cultura profissional dos professores, acima identificadas.

Para um melhor entendimento do quadro 2 será conveniente referir que o conceito de estilos de uso do conhecimento pretende distanciar-nos das problemáticas teóricas sobre a reflexividade docente que se constroem em torno do conceito de "teoria prática" e de "teoria implícita" (cf. Tochon 1998 [1996]). Tal distanciamento resultou de duas reflexões complementares mais recentes (Caria 2005a; 2005b). Por um lado, verificámos que o desencadeamento das 
Quadro 2

Tipologia dos estilos de uso do conhecimento

\begin{tabular}{|c|c|c|c|c|}
\hline $\begin{array}{l}\text { Mente } \\
\text { cultural }\end{array}$ & \multicolumn{2}{|c|}{$\begin{array}{l}\text { Uso de conhecimento- } \\
\text {-informação }\end{array}$} & \multirow[b]{2}{*}{$\begin{array}{c}\text { Estilos de uso } \\
\text { do conhecimento }\end{array}$} & \multirow[b]{2}{*}{$\begin{array}{c}\text { Formas de uso } \\
\text { da cultura } \\
\text { profissional }\end{array}$} \\
\hline $\begin{array}{c}\text { Sentido } \\
\text { contextual } \\
\text { [como fazer? } \\
\text { como falar?] }\end{array}$ & $\begin{array}{c}\text { Sentidos } \\
\text { interpretativos } \\
\text { e justificativos } \\
\text { [porquê?] }\end{array}$ & $\begin{array}{l}\text { Sentidos } \\
\text { técnicos } \\
\text { e estratégicos } \\
\text { [para quê?] }\end{array}$ & & \\
\hline- & - & - & Ausência de uso & \multirow{2}{*}{$\begin{array}{c}\text { Domesticação } \\
\text { da cultura }\end{array}$} \\
\hline$++\mathrm{ou}+$ & - & - & Uso tradicional & \\
\hline- & + & - & $\begin{array}{l}\text { Uso ideológico } \\
\text { ou crítico-retórico }\end{array}$ & \multirow{3}{*}{$\begin{array}{c}\text { Escolarização } \\
\text { da cultura }\end{array}$} \\
\hline- & - & + & $\begin{array}{c}\text { Uso tecnicista } \\
\text { ou técnico-instrumental }\end{array}$ & \\
\hline- & + & + & $\begin{array}{l}\text { Uso pericial clássico } \\
\text { ou dogmático }\end{array}$ & \\
\hline+ & + & - & Uso crítico-teórico & \multirow{2}{*}{$\begin{array}{c}\text { Formas mitigadas } \\
\text { de racionalização } \\
\text { da cultura }\end{array}$} \\
\hline+ & - & + & Uso crítico-pragmático & \\
\hline$++\mathrm{ou}+$ & + & + & $\begin{array}{l}\text { Uso pericial crítico } \\
\text { (plena articulação } \\
\text { das mentes sociais) }\end{array}$ & $\begin{array}{l}\text { Racionalização } \\
\text { da cultura }\end{array}$ \\
\hline
\end{tabular}

Legenda: (-) existência fraca; $(+)$ existência forte; $(++)$ existência muito forte.

operações de recontextualização do conhecimento-informação começavam por submeter a forma das teorias abstractas à lógica da acção (uso profano ou selvagem da ciência, cf. Nunes 2000): deixava-se de dar importância àquilo que academicamente é identificado como a forma da teoria (a coerência dos seus postulados, o rigor dos conceitos, a sistematização dos argumentos e a precisão das afirmações-factos). Passava-se a usar de modo disperso e circunstancial os conteúdos informativos, contidos nos conhecimentos interpretativos ou estratégico, e que são relevantes para agir. Por outro lado, verificámos que a reflexividade na acção e da acção (expressa nas trocas simbólicas entre professores no seu quotidiano) não evoluíam em geral (como seria esperado numa teoria em estado implícito) para uma reflexividade sobre a acção, permanecendo centradas na organização do conhecimento que tinha sentido para perpectuar uma tradição local. Não há, portanto, teorias práticas. Apenas há processos 
de recontextualização da teoria, com mais ou menos relevância contextual (no quadro indica-se maior ou menor sentido contextual).

Também no âmbito da análise de outros grupos profissionais e inspirados em Bernard Charlot (2000 [1997]), passámos a falar em sentidos do conhecimento, e não em tipos de conhecimento. Percebemos que o conceito de saber, que pretendíamos enfatizar, não era compatível com o isolamento de componentes ou qualidades do conhecimento, relativas ou não à origem institucional do conhecimento (tipos científicos, filosóficos, técnicos, etc.): o saber dependia somente da relação que os sujeitos têm com o conhecimento. Deste ponto de vista, acrescentaria ao que afirmei atrás, que o sentido estratégico implica uma relação com o conhecimento que tem como finalidade excluir e incluir (velhas e novas) acções no encadeamento espacio-temporal das rotinas no sistema social (cf. Giddens 1989; 1992) e que o sentido interpretativo implica uma relação com o conhecimento que tem como finalidade justificar (legitimar ou criticar) uma certa ordem social e simbólica.

Retomando o quadro 1, poderemos ainda acrescentar, por hipótese, que o conceito de informação-qualificação tem relações privilegiadas com o conceito de sentido interpretativo, dado em ambos os casos nos referirmos a enunciados verbais que explicitam conflitos de legitimidade social. E que o conceito de informação-competência tem relações privilegiadas com o conceito de sentido estratégico, dado em ambos os casos e de acordo com as definições dadas atrás, nos referimos a "habilidades intelectuais" capazes de inserir ideias abstractas na acção.

Entrando no detalhe do conteúdo do quadro 2, começaremos por destacar os quatro estilos de uso do conhecimento que, por ordem, mais frequentemente são referenciados na bibliografia como específicos do trabalho intelectual-técnico, a saber:

1) A chamada racionalidade técnico-instrumental (que podemos designar de estilo técnico-instrumental, na $4 .{ }^{a}$ linha do quadro 2) como forma de descrição do trabalho técnico-intelectual parece supôr um estilo em que o sentido técnico-estratégico é sobrevalorizado e instrumentalizado pelo poder político, facto que faz com que o sentido contextual e o sentido interpretativo da profissão tenham pouca relevância no trabalho técnicointelectual, transformando as opções e alternativas de acção em protocolos estandardizados de procedimento ou modelo de acção fixos, apresentandoos como as únicas formas possíveis de agir adequadamente por relação a fins, não sendo estes questionados (cf. Habermans 1993 [1968]);

2) $\mathrm{O}$ chamado uso pericial do conhecimento (que podemos designar de estilo pericial clássico, na 5. ${ }^{\mathrm{a}}$ linha do quadro 2) como forma de descrição do trabalho técnico-intelectual parece supor um estilo em que os sentidos técnico-estratégico e interpretativo-justificativo são sobrevalorizados e, em consequência, pouco recontextualizados e articulados com o sentido 
contextual, consequência de o perito manipular modelos de acção-interpretação que estão pouco atentos à singularidade das situações, aos seus aspectos relacionais e imprevisíveis, facto que o faz ser visto pelos leigos e clientes como desenvolvendo uma actividade dogmática, implicando da parte destes uma relação de confiança-fé com o conhecimento-informação de origem científica (cf. Madureira e Rocha 2002; Dubreuil 2000);

3) A chamada profissionalidade reflexiva (que podemos designar de estilo pericial crítico), que como forma de descrição do trabalho técnico-intelectual supõe um estilo de uso do conhecimento (última linha do quadro 2) que supera totalmente as limitações da racionalidade técnico-instrumental, aceitando-se que o trabalho técnico possa invadir as áreas decisionais e políticas das organizações e que o uso da ciência na sociedade não é apenas uma mera aplicação de princípios e regras gerais, dado implicar um conhecimento experiencial ou uma "arte" que estão atentas às particularidades dos contextos, às incertezas dos sistemas e às configurações singulares das situações-problema (Shon 1998; cf. Caria 2003b; cf. Filipe 2003b);

4) O chamado uso crítico-teórico do conhecimento ( $6{ }^{a}$ linha do quadro 2$)$ que como forma de descrição do trabalho técnico-intelectual supõe um uso do conhecimento profundamente académico, onde o sentido explicativo-interpretativo está sobrevalorizado e bem validado em dados empíricos, contextualizados ou não, mas que carece da subjectividade do autor, expressa no sentido estratégico, para que o conhecimento faça sentido quando este tem que agir, designadamente na articulação entre o "como" e o "para quê".

Os restantes três estilos de uso do conhecimento, presentes no quadro 2, são relativos àqueles que, por ordem, mais encontrámos no meio profissional dos professores que investigámos, a saber:

5) O chamado uso tradicional (2. ${ }^{\text {a }}$ linha do quadro 2$)$ que como forma de descrição do trabalho técnico-intelectual supõe um forte constrangimento da interacção social sobre cada indivíduo, permitindo aos pares mais velhos sinalizar e sancionar o que é tido como não usual e não esperado pelo grupo, sendo reforçada tal acção através da justificação implícita de narrativas que referem o que é costume, na relação com a experiência colectiva acumulada historicamente em contexto;

6) O chamado uso ideológico (3. ${ }^{a}$ linha do quadro 2 ) que como forma de descrição do trabalho técnico-intelectual supõe que o conhecimento tenha apenas valor retórico para criticar a ordem institucional do real, desenvolvendo o sentido interpretativo e tornando particulamente visíveis socialmente as contradições entre discurso e prática sociais, pois tal crítica não tem qualquer relação com a acção quotidiana, designadamente com orientações estratégicas e contextuais; 
7) O chamado estilo de uso crítico-pragmático (penúltima linha do quadro 2), que como forma de descrição do trabalho técnico-intelectual supõe que o sentido interpretativo é desvalorizado em favor da capacidade de os actores sociais associarem à prática uma grande procura de inovação social, inspirada em valores sociais críticos da realidade existente, embora sem capacidade para interpretar os resultados que se vão obtendo e reagir face a eles; traduz-se numa fraca reflexividade a posteriori sobre os processos de interacção, consequência da não existência de uma linguagem profissional específica, suficientemente precisa e rigorosa para dar conta dos efeitos das regularidades na acção social, isto é, uma fraca subjectivação da reflexividade institucional em educação.

Finalmente, será importante frisar um último aspecto, relativo à $1{ }^{a}{ }^{a}$ linha do quadro 2: quando falamos de uso do conhecimento estamos a desenvolver uma problemática teórica que tem como pressuposto algum nível de consciência dos actores sociais sobre o conhecimento que utilizam, directamente ligado aos processos de interacção social. Neste caso, a indicação no quadro de uma força fraca (sinal "-") no uso de todos os sentidos do conhecimento tem tradução no facto de os actores sociais não terem qualquer tipo de consciência sobre o conhecimento em uso. Este ponto de vista tem como pressuposto teórico que a prática social tem várias modalidades de regulação (Caria 2002b; 2002c; 2004b; Dubet 1996 [1994]; Shalins 1980): ${ }^{10}$ (a) o habitus (prática social sem consciência, pré-reflexiva); (b) a interacção social (prática-acção social) em que se pressupõe a consciência prática dos actores sociais; (c) a instituição-campo (conduta social vista como papel social ou posição/tomada de posição num campo social) em que se pressupõe a consciência discursiva dos actores sociais para fazerem reconhecer estatutos sociais ou terem o domínio simbólico da prática. Deste modo, a existência de qualquer tipo de consciência no uso do conhecimento supõe sempre sentidos contextuais que não são fracos e que, portanto, nos quais é determinante a regulação da prática pela interacção social.

\section{TERCEIRA FASE DA APRENDIZAGEM: SUPERAR LIMITAÇÕES ANALÍTICAS}

A minha reflexão teórica sobre grupos profissionais desenvolve-se ainda num terceiro momento, que vai de 1999/2000 até ao final de 2005. Corresponde ao período de tempo em que debato e comparo com a equipa de investigação,

10 No mesmo sentido parece ir a reflexão teórico-emprírica de Bernard Lahire (1998) ao criticar, em Bourdieu, a redução da conduta social apenas a uma prática pré-reflexiva e a disposições incorporadas do passado. Nesta linha de raciocínio, este autor enfatiza a importância da ocasião e do acontecimento presente, como determinantes da prática, e a importância dos usos da linguagem e da escrita como instrumentos de objectivação e formalização da subjectividade (não circunscrevendo o conhecimento da prática apenas à teoria abstracta). 
a que me referi na secção 1 , os dados empíricos que tínhamos recolhido sobre o trabalho intelectual-técnico em vários grupos profissionais (Caria 2001a; 200lb; 2002d; 2003a; 2005b; Filipe 2003a; 2003b; Pereira 2003; 2005), fazendo ao mesmo tempo uma releitura do trabalho etnográfico que tinha desenvolvido com professores no passado.

Como referi no início da secção anterior, a minha reflexão entre 1993 e 1999 era analiticamente limitada. Tinha encontrado configurações variadas de separação (e não tanto de articulação) entre as mentes sociais que dependiam de processos mais ou menos conseguidos de recontextualização profissional e de tradicionalismo local. Tratava-se de configurações que dependiam de sentidos contextuais no uso do conhecimento, mais ou menos fracos. Reconhecia-se uma certa dualidade das mentes sociais, porque para uma parte significativa do grupo social o contexto de uso do conhecimento não deixava de coexistir e mobilizar conhecimento abstracto. Mas, ao contrário daquilo que se procurava, a dualidade era principalmente dualista: era capaz de mobilizar conteúdos e significados informativos e abstractos exteriores à lógica da teoria abstracta, mas as formas de uso não serviam plenamente o contexto profissional de interacção local. Eram formas retóricas ou formas individualistas. As formas de uso que se procuravam, que permitiriam a plena integração do conhecimentoinformação no contexto profissional e consequente capacidade para formalizar e negociar o saber prático colectivo, não existiam

Penso que o desenvolvimento que demos ao nosso trabalho com professores, em torno dos estilos de uso do conhecimento, também põe em evidência quanto continuámos dependentes das teorias que se constroem a partir das hierarquias legítimas de informação. De facto, a possibilidade de partimos de uma qualquer mente cultural para uma mente racional-positiva é desvalorizada quando se privilegiam os processos de recontextualização profissional. Continua-se a centrar o foco de análise nos efeitos de poder que decidem o que adquirir e o que oferecer como conhecimento aos outros. Em conclusão, na etnografia sobre a cultura profissional do professor continuei aquém da perspectiva de pensar a mobilização do conhecimento a partir da problemática do saber.

Assim, posso dizer que, no início deste novo período de aprendizagens, tinha uma orientação para a construção de um modelo sociocognitivo de análise dos grupos profissionais que estava incompleto. Pressupunha apenas uma direcção no uso contextual do conhecimento, a recontextualização Faltava-me pensar a direcção inversa: a transferência de conhecimento (cf. Frenay 1996). Para isso, como vim a escrever neste período (Caria 2002a: 816-823; 2005a), as culturas profissionais desenvolviam-se a partir de um enquadramento metodológico que se desdobrava em dois movimentos reflexivos:

$\S$ a recontextualização de conhecimento-informação, destinada a descobrir as possibilidades de aplicação de regras e princípios gerais (de acção e 
interpretação) a situações particulares, percebendo-se como se pode recontextualizar uma mente racional positiva (reflexividade institucional);

$\S$ a transferência deconhecimento-saber entre diversos contextos, destinada a descobrir o que existe de comum e generalizável entre singularidades diversas, capazes de formalizar e colectivizar os procedimentos e as linguagens que permitem desenvolver uma mente racional-positiva a partir da comparação entre contextos de acção (reflexividade interactiva).

Para ultrapassar as limitações analíticas em que havia caído precisei, ainda, de clarificar que a dualidade na organização das mentes sociais supõe considerar três pressupostos/hipóteses que exprimem a ideia de uma prioridade da aprendizagem da mente cultural sobre a mente racional-positiva (Caria 2004a), a saber:

$\S$ o trabalho técnico-intelectual quando desenvolve um sentido contextual forte faz com que o profissional comece por ser um prático, antes de ser um intelectual, porque o sentido da acção começa por se construir na interacção social;

$\S$ o sentido contextual forte no uso do conhecimento torna o saber autónomo do conhecimento-informação, dado poder ser apenas determinado pelas procuras e usos de conhecimento dos profissionais, enquanto práticos;

$\S$ o saber de um prático, ainda que se organize no face-a-face, não tem que se limitar a uma acção apenas à escala local, especialmente se estamos em presença de um trabalho técnico-intelectual, em virtude de existir conhecimento-informação que permite ir para além da interacção local.

De um ponto de vista antropológico, a organização de dois tipos qualitativamente diferentes de conhecimento parece ter toda a validade, pois vem de longe na história desta disciplina a ideia de uma dualidade nas mentes sociais (a do primitivo e a do ocidental). Esta abordagem etnocêntrica, dualista e dicotómica tem uma crítica e uma proposta alternativa nos trabalhos de Jack Goody (1987; 1988). É esta perspectiva que permite a Raúl Iturra, como vimos na secção 2, tratar da questão da escolaridade supondo a hipótese de duas mentes sociais que se podem articular. Não se confunde dualidade com dualismo, porque à luz das considerações apresentadas para superar as nossas limitações analíticas, existe uma prioridade do social sobre o psicológico e do cultural sobre o racional. Esta orientação obriga-nos a valorizar mais a mobilização sociocognitiva que transfere conhecimento e menos a que recontextualiza.

A concepção de uma dualidade na mobilização do conhecimento, parece também ter validade para a investigação mais recente em ciências cognitivas, especialmente aquela que tem inspiração fenomenológica (cf. Damásio 1994; Castro Caldas e Reis 2000; Varela e outros 2003 [1991]; Karmiloff-Smith 
1995; Ventura e outros 2002; Sun 2002; cf. Bennett e Hacker 2005). Para os propósitos deste texto, será de destacar, como refere Ron Sun (2002: 21 32 ), que o funcionamento/aprendizagem cognitivo na acção quando manipula formas de conhecimento quotidiano pode ser desdobrado em duas dimensões: as representações de significados e a regulação da acção. Ambas ocorrem contextualmente sem terem que convocar conhecimento-informação, podendo por isso ser consideradas como dimensões do funcionamento sociocognitivo da mente cultural.

Segundo este autor, as ciências cognitivas caíram no erro de pensar que poderia haver uma tradução imediata e automática entre a explicitação (verbalização) de representações/significados contextuais e uma representação da acção organizada por regras explícitas. Assim, a investigação sobre a cognição na acção constatou que não é por haver uma explicitação de regras para a acção que automaticamente temos uma representação completa quanto ao sentido do mesmo contexto de acção e vice-versa.

O quadro 3, traduzido do formulado por Sun (2002: 26), permite dar conta dos eventuais desfasamentos entre as duas dimensões do funcionamento cognitivo. Mostra, segundo a minha perspectiva, que o implícito e prático (posição inferior direita do quadro) pode desenvolver-se tanto para um implícito regulado (posição inferior esquerda do quadro) como para um explícito improvisado (posição superior direita do quadro). A equivalência entre representações e regulações é apenas uma das modalidades possíveis do funcionamento/aprendizagem cognitivo (posição superior esquerda do quadro). Penso que o quadro permite perceber as modalidades de funcionamento/aprendizagem cognitivo em contexto e esclarece o que se pode entender por um sentido contextual mais fraco ou mais forte. Mais especificamente, o sentido contextual será tanto mais forte quanto o saber prático é capaz de associar explicitamente representação de significados

\section{Quadro 3}

Modelo de uso do conhecimento na acção de Ron Sun

Representações/significados contextuais explícitos

Regras de acção (regras explícitas)

Representações/significados contextuais implícitos

Acção regulada (s/ representações explícitas)
Representações/significados contextuais explícitos

Acção improvisada

Representações/significados contextuais implícitos

Ausência de acção regulada 
(verbalizações) e regras de acção (quadrante superior esquerdo do quadro 3). No dizer de Terssac (1998 [1996]: 237-240), a prática para ser consciente, para poder ser "saber em situação", terá que se traduzir numa "competência-explicitação" capaz de gerir as associações entre o "saber-dizer" e "saber-o-que fazer". Acrescento: explicitações que se tornam determinantes para que a mente cultural possa recontextualizar plenamente o conhecimento-informação.

Esta hipótese encontrava algumas evidências empíricas a seu favor no meu trabalho etnográfico com professores quando analisei os processos de interacção em reuniões formais entre pares. Neste caso, as explicitações de representações e acções e as aproximações ao conhecimento abstracto dependiam do uso da escrita, quando esta cumpria duas condições simultaneamente (Caria 2000: 307:408): 1) era instrumento reflexivo de formalização de sequências de acção e de negociação de significados no processo de interacção local; 2) ocorria em espaços-tempos que estão codificados pelas normas abstractas da instituição escolar, mas em que os actores sociais têm margens de autonomia para delas fazerem reinterpretações próprias.

Trata-se de uma hipótese que carecia de outras evidências empíricas e de uma melhor formulação teórica, mas que definitivamente nos reorientava para um modelo sociocognitivo de análise das culturas profissionais que tem um novo centro: as especificações do saber que podem contribuir para perceber os processos de transferência do conhecimento e suas articulações com as recontextualizações do mesmo.

\section{TENTATIVA FINAL DE SÍNTESE PARA DEBATE: OS SENTIDOS DO SABER}

Como deixei claro atrás, nas secções 4 e 5 , a possibilidade de se regressar a uma análise sociocognitiva das desigualdades na escolaridade básica depende de um aprofundamento da problemática do saber e, portanto, das aprendizagens que acabei de descrever. Assim, actualmente as minhas reflexões e aprendizagens organizam-se em torno de três interrogações:

$\S$ quais os sentidos em que o conhecimento-saber (prático-contextual) se pode desdobrar?;

$\S$ que factores sociais permitem explicitar sentidos no conhecimento-saber, que superem a lógica do habitus?;

$\S$ quais os sentidos do saber que podem ser articulados com os sentidos relativos ao uso do conhecimento-informação?

Para responder à primeira interrogação, cruzámos várias contribuições de membros do nosso seminário-equipa de investigação (Filipe, 2003a; 2003b, Pereira 2003). Trata-se de contribuições que me chamaram a atenção para aspectos pontuais e dispersos da minha etnografia com professores que na altura não tinham especial significado teórico (Caria 2005b), a saber: 
$\S$ na interacção entre pares, a narração e a referência continuada a acontecimentos locais passados serviam a (re)construção de uma memória oral colectiva e dava um valor simbólico acrescido (ritual?) a determinados episódios recordados (hipótese de um sentido narrativo-ritual);

$\S$ na interacção entre pares, as categorias de linguagem comum utilizadas (cf. Quéré 1994) e a negociação de significações a elas associadas estavam ligadas a reapropriações locais das classificações instituídas (normas) de interpretação do mundo (hipótese de um sentido categorial-normativo);

$\S$ na interacção entre pares, existiam procedimentos, implicados nas rotinas, de uso dos recursos disponíveis e possibilidades de os adequar (no momento seguinte em que a rotina é prosseguida ou repetida) para melhor corresponderem às expectativas comuns de reciprocidade na interacção (hipótese de um sentido procedimental-relacional, cf. Pereira 2003).

A conjugação destes factos com a estrutura do quadro 3 de Ron Sun permite-nos chegar a um esquema conceptual que contém uma terminologia adaptada à lógica do nosso raciocínio (quadro 4). Para melhor entender este importará tomar em consideração que:

$\S$ no caso de não existirem significados e acções explícitas (correspondente ao espaço inferior direito do quadro), isso quererá dizer que os actores sociais não têm qualquer consciência (nem mesmo consciência prática) do conhecimento que mobilizam no quotidiano e, em consequência, não

\section{Quadro 4}

\section{Modalidades do saber prático-contextual}

\begin{tabular}{ccc} 
& \multicolumn{2}{c}{ Regras de acção em contexto } \\
\cline { 2 - 3 } Significações & Explicitação & Não explicitação \\
contextuais & de sequências & de sequências \\
& de acção & de acção
\end{tabular}

Significados explicitados na linguagem verbal em interacção

Significados sem explicitação na linguagem verbal em interacção
O sentido procedimental é acompanhado e complementado pelo sentido categorial e vice-versa (sentido contextual forte!)

O sentido procedimental está enfatizado sem estar acompanhado pelo sentido categorial (sentido contextual fraco?)
O sentido categorial está enfatizado sem ser acompanhado pelo sentido procedimental (sentido contextual fraco?)

Inexistência de saberes práticos (prática social apenas regulada pelo habitus) 
poderemos afirmar que existe um saber, pois no essencial a conduta é uma prática social apenas regulada pelo habitus e pelo passado incorporado;

$\S$ o papel desempenhado pelo sentido narrativo é omisso, porque, ou remete para uma problemática, que ainda não desenvolvemos, relativa ao valor explicativo da emoção na acção social (cf. Barbalet 2001 [1998]), ou remete para hipóteses que são dependentes do uso do conhecimento abstracto (ver mais à frente nesta secção);

$\S$ os casos de desfasamentos entre a explicitação de significados e acções em contexto (correspondentes aos espaço inferior esquerdo e superior direito do quadro) têm uma interrogação quanto à força do sentido contextual, porque as várias hipóteses que posso colocar são dependentes do uso do conhecimento abstracto (ver mais à frente nesta secção).

Penso, ainda, que o quadro 4 permite colocar algumas hipóteses em resposta à segunda questão formulada no início desta secção: qual a possibilidade de se desenvolverem representações e acções explícitas em práticas sociais?

A tendência mais comum nas ciências da educação é para responder que tal depende apenas dos processos de educação não formal e informal ou da articulação destes com a educação formal, como se uma maior explicitação de saberes decorresse apenas da vontade dos actores sociais em presença ou das pedagogias e modelos de formação. Sem prejuízo desta abordagem, preferimos enfatizar o facto de a reflexividade interactiva, resultante da explicitação dos sentidos do saber contextual, depender de relações de poder mais vastas que se definem em conjunturas de mudança à escala micro. É neste quadro, como referi noutros trabalhos (Caria 2002a; 2002c; 2004a), que se torna necessária uma análise conjuntural da prática que permita perceber como é que as mudanças sociais (intergeracionais, intrageracionais e institucionais) interferem e perturbam a reprodução social de um grupo localizado e regulado pela interacção social, a saber:

$\S$ como e em que medida é que o património cultural passado de um grupo social é actualizado face ao desfasamento histórico entre gerações?

$\S$ como e em que medida é que a heterogeneidade de origens e trajectórias sociais contidas num determinado grupo social é objecto de um trabalho simbólico de homogeneização sobre si próprio, para poder apresentar-se como um único grupo-cultura na acção?

$\S$ como e em que medida é que as mudanças institucionais e organizacionais, condicionadas por políticas públicas nacionais ou privadas globais, são interpretadas e implementadas pelos actores sociais localmente, tomando por referência as suas tradições de acção?

Em torno destes tópicos julgamos poder afirmar que a necessidade, ao nível micro, de se saber gerir os efeitos das mudanças sociais mais vastas, leva os actores sociais a realizarem localmente e em interacção pequenas explicitações 
da linguagem comum (com verbalizações de representações quotidianas) e pequenas adaptações de rotinas (com explicitação de sequências de acção). Em consequência, os actores sociais são convocados para a necessidade de desenvolverem o que conceptualizámos como $o$ sentido procedimental e $o$ sentido categorial do saber prático-contextual.

Assim, poderemos dizer que existe uma acepção conjuntural da cultura quotidiana que permite superar o estado pré-reflexivo da prática social (habitus), em virtude da necessidade de, face à mudança social, se desenvolverem improvisações prático-locais que estão para além da simples reprodução/actualização do passado incorporado (histerese do habitus) de um dado grupo social (cf. Costa 1999: 289-306). São improvisações que visam responder a situações que, ao nível da consciência prática, são reconhecidas como inesperadas por frustrarem as expectativas recíprocas presentes na interacção social. Como poderia dizer Raúl Iturra (1988): são improvisações e situações que revelam a mente cultural na conjunturalidade das relações sociais.

Por fim, vejamos a terceira interrogação, apresentada no início desta secção: quais os sentidos do saber contextual que podem ser articulados com os sentidos relativos ao uso do conhecimento-informação?

A resposta mais imediata a esta questão, que foi desenvolvida num noutro trabalho (Caria 2002a), é a seguinte:

$\S$ o sentido procedimental é articulável com o sentido estratégico, na medida em que as pequenas adaptações nas rotinas do processo interactivo, para responder à frustração de expectativas, sejam integradas em escolhas de caminhos/fins alternativos mais vastos;

$\S$ o sentido categorial é articulável com o sentido interpretativo, na medida em que as negociações/verbalizações de significados desenvolvidas no processo interactivo, para responder à frustração de expectativas, sejam integrados em enunciados discursivos que dão conta de regularidades e ordens sociais e simbólicas mais vastas;

$\S$ estas articulações, entre o procedimental-estratégico e o categorial-interpretativo, dependem do uso de uma escrita reflexiva, enquanto instrumento formalizador e regulador da autonomia dos grupos sociais localizados.

Actualmente, face aos mais recentes resultados de investigação sobre grupos profissionais obtidos pelo nosso seminário-equipa ASPTI, podemos colocar mais algumas hipóteses que directamente têm a ver com as possíveis articulações entre as duas mentes sociais (Caria 2005b). Elas aproximam-se, em parte, de hipóteses também formuladas por Terssac (1998 [1996]: 240-246), a saber:

$\S$ a articulação dos sentidos procedimental e estratégico pode ter implicações na força do sentido contextual, passando-o de fraco a forte (clarifica a interrogação sobre o sentido fraco no espaço superior direito do quadro 4); 
$\S$ a articulação dos sentidos categorial e interpretativo pode estar associada à definição daquilo que designámos como qualificação na dependência do saber (uma qualificação-saber);

$\S$ a articulação dos sentidos procedimental e estratégico pode estar associada à definição daquilo que designámos como competência na dependência do saber (uma competência-saber);

$\S$ a articulação dos sentidos categorial e interpretativo pode ter implicações na força do sentido contextual, passando-o de fraco a forte (clarifica a interrogação sobre o sentido fraco no espaço inferior esquerdo do quadro 4 e permite descrever melhor o que é o estilo crítico pragmático de uso do conhecimento, indicado no quadro 2);

$\S$ a articulação dos sentidos procedimental-categorial-narrativo pode ter implicações na força do sentido contextual, tornando-o, ainda, mais forte (clarifica o que é um sentido contextual muito forte $[++]$, assinalado no quadro 2), tendendo nesse caso a excluir o uso do conhecimento abstracto e a descrever melhor o que é o estilo tradicional de uso do conhecimento (indicado no quadro 2 ).

Julgo que este conjunto de hipóteses me coloca em situação de poder regressar à perspectiva sociocognitiva sobre o problema das desigualdades na escolaridade básica. Embora permaneça sem uma resposta empiricamente fundamentada e específica para o problema, o itinerário que descrevi evidencia a necessidade de se olhar para as aprendizagens pelo lado do saber, dos sentidos prático-contextuais que se manifestam na interacção social, sem esquecer que estes para se desenvolverem têm que se articular com sentidos de uso do conhecimento-informação.

A possível consequência desta descrição, para a interacção social escolar, é a de que na escolaridade básica tem que: a) saber-se apresentar situações inesperadas que desafiem os saberes já possuídos pelos aprendizes, de modo a permitir transferências de conhecimento-saber; b) saber-se apresentar situações já conhecidas nas quais se possa aplicar, por recontextualização, conhecimento-informação novo. Trata-se, portanto, de pensar a aprendizagem escolar permanecendo fiel à premissa piagetiana de que o desenvolvimento cognitivo se dá pelo conflito e desequilíbrio entre o velho e novo, entre o esperado já organizado e o inesperado, que desafia o pensamento. Inversamente, como mostrou Bourdieu, todos os automatismos do pensamento e da acção que não sabem lidar com o inesperado e o novo, ao nível da consciência prática, traduzem-se sempre em sentidos práticos incorporados que perpetuam desigualdades na reprodução social. Penso que para fugir a estes automatismos temos que dar conta da dualidade cognitiva das mentes sociais que estão envolvidas na mobilização do conhecimento, e não as reduzir uma à outra.

No entanto, é preciso perceber que o novo e o velho não estão só no conhecimento-informação, mas sim, principalmente, no saber envolvido nas situações 
locais, embora sem cair na ilusão subjectivista de pensar que basta a acumulação de saber local para que automaticamente se consiga ter acesso ao conhecimento-informação mais geral. É também preciso perceber que as situações que permitem recontextualizar não são as mesmas que permitem transferir conhecimento. É aqui que se revela a dualidade na mobilização sociocognitiva e que julgamos ser muito mal entendidas no ensino escolar: os processos do saber não operam em simultâneo com os processos informativos.

\section{CONCLUSÕES: ESCOLHAS E SABERES NA PRÁTICA DA CIÊNCIA}

Regressemos ao tema metodológico inicial, de introdução a este texto: o que nos mostra este itinerário de aprendizagens sobre a construção teórico-biográfica do objecto saber? A construção de um objecto teórico é um lento caminhar (pensamento e acção) que vai encontrando respostas, sempre incompletas e abertas. Depois de 15 anos de investigação e aprendizagens, o meu problema teórico inicial, das modalidades em que as desigualdades escolares são reproduzidas, continua em aberto, tendo sido em grande parte abandonado. No entanto, sem o ter planeado, encontro-me hoje, se desejar escolher esse caminho, em condições de poder retomar a sua análise, desde que esta conceptualização sobre o conhecimento-saber se revele válida.

Digo que não planeei este trajecto profissional, mas isso não pretende afirmar que tenha sido inconsciente no caminho que trilhei ou que o meu problema teórico central se tenha dissolvido. Por um lado, as contradições, os obstáculos e as limitações que descrevi neste itinerário, reveladoras dos meus conflitos e desequilíbrios cognitivos entre o que já sabia e o que aprendia como novo, mostram que fiz escolhas entre as possibilidades que o terreno empírico e os recursos teóricos disponíveis permitiam. Por outro lado, o problema teórico inicial não foi dissolvido, embora tenha permanecido sem resposta (como dizia, foi em parte abandonado) ao nível da minha consciência prática de investigador, revelando-se aqui e ali na linguagem comum e especializada de descrição da investigação (cultura profissional das ciências sociais) através da interacção social que tinha oportunidade de desenvolver com os meus pares de profissão que trabalhavam em temas próximos.

Em conclusão, diria que, para além e aquém das regras de legitimação dos problemas científicos num dado campo disciplinar, existe uma cultura de problemas práticos quotidianos que se podem exprimir num conhecimento-saber de experiência científica acumulada ao longo de um trajecto profissional. É este saber experiencial que nos revela a conjunturalidade da produção científica, sendo através dela que aprendemos a saber ser cientistas sociais.

Em síntese, descrevi neste itinerário as escolhas não planeadas e os problemas científicos quotidianos, que são um exemplo do modo biográfico de emergência de um discurso legítimo em Ciências Sociais. Espero que esta 
contribuição possa trazer bons usos didácticos e pedagógicos na educação em ciências sociais.

Pergunta final: será possível descrever a construção teórica de um objecto de investigação, de um modo semelhante àquele que aqui faço, sem que se tenha desenvolvido uma epistemologia prática de carácter etnográfico? Não sei responder à pergunta, mas gostaria que os meus pares - profissionais reflexivos das ciências sociais que utilizam outras epistemologias práticas na investigação - dessem a sua resposta.

Vila Real, Dezembro de 2005

\section{BIBLIOGRAFIA}

ALMEIDA, João Ferreira, 2003, Cuzamento de Saberes, Aprendizagens Sustentáveis. Lisboa, Fundação Calouste Gulbenkian.

BARbAlet, J.M., 2001 [1998], Emoção, Teoria Social e Estrutura Social. Lisboa, Instituto Piaget.

BARBIER, Jean-Marie (org.), 1998 [1996], Savoir Théorique et Savoirs d'Action. Paris, PUF.

BELLIER, Sandra, 2003 [1999], "A competência”, in Carré e Caspar (orgs.), Tratado das Ciências e das Técnicas da Formação. Lisboa, Instituto Piaget, pp. 241-262.

Benavente, Ana (org.), 1996, A Literacia em Portugal. Resultados de uma Pesquisa Extensiva e Monográfica. Lisboa, Fundação Calouste Gulbenkian/Conselho Nacional de Educação.

BENNETT, M.R., e P.M.S. Hacker, 2005, Fundamentos Filosóficos da Neurociência. Lisboa, Instituto Piaget.

BERNSTEIN, Basil, 1990, The Structuring of Pedagogic Discourse. Londres, Routledge.

_ 1 1996, Pedagogy, Symbolic Control and Identity. Londres, Taylor \& Francis.

BONAL, Xavier, e Xavier Rambla, 1999, "Sobre a reflexividade em Sociologia da Educação e estruturação social”, Educação, Sociedade e Culturas, n. ${ }^{\circ}$ 12, pp. 230-234 [réplica ao comentário crítico de Telmo Caria].

BOURDieU, Pierre, 1979, La Distintion - Critique Social du Jugement. Paris, Minuit.

— 1987, Economia das Trocas Simbólicas. São Paulo, Perspectivas.

BOURDIEU, Pierre e Jean-Claude Passeron, 1978, A Reprodução - Elementos para uma Teoria do Sistema de Ensino. Lisboa, Vega.

CARIA, Telmo H. (1992a), "As finalidades sociológicas da educação na formação de professores“, em Stephen Stoer e António Esteves (orgs.), A Sociologia na Escola - Professores, Educação e Desenvolvimento. Porto, Afrontamento, pp. 259-274.

— 1992 b, "Perspectiva sociológica sobre o conceito de educação e a diversidade das pedagogias”, Sociologia - Problemas e Práticas, n. ${ }^{\circ}$ 12, pp. 50-70. 
CARIA, Telmo H., 1999a, "A estruturação social e a reflexibilidade: as limitações da sociologia da educação", Educação, Sociedade e Culturas, n. ${ }^{\circ}$ 12, pp. 223-229 [comentário crítico ao artigo de Xavier Bonal e Xavier Rambla (1996), publicado no n. ${ }^{\circ} 9$ da mesma revista].

— 1999 b, "A racionalização da cultura profissional dos professores - uma abordagem etno-sociológica no contexto do $2 .^{\circ}$ ciclo do ensino básico", Revista Portuguesa de Educação, vol. XII (1), pp. 205-242.

— 2000, A Cultura Profissional dos Professores - o Uso do Conhecimento em Contexto de Trabalho na Conjuntura da Reforma Educativa dos Anos 90. Lisboa, Fundação Calouste Gulbenkian/ Fundação para a Ciência e Tecnologia [versão actualizada e revista da tese de doutoramento defendida em 1997].

—_, 2001a, "A Universidade e a recontextualização profissional do conhecimento abstracto - hipóteses de investigação e acção política", Cadernos de Ciências Sociais, n. ${ }^{\circ} 21$-22, pp. 71-85.

—_, 2001b, Notas sobre a relação profissões e uso da ciência: os casos dos médicos veterinários e dos animador-técnico do desenvolvimento. Vila Real. IV seminário ASPTI, documento de trabalho ASPTI n. ${ }^{\circ} 15$ (policopiado).

— 2002 a, "O uso do conhecimento: os professores e os outros", Análise Social, n. ${ }^{\circ}$ 164, pp. 805-831.

— 2002 b, "Dos dualismos de sentido aos usos sociais das teorias educativas", Educação, Sociedade e Culturas, 18, pp. 149-169 [comentário crítico ao artigo de Rui Gomes (2001), publicado no n. ${ }^{\circ} 16$ da mesma revista].

—, 2002 c, "Da estrutura prática à conjuntura interactiva: relendo o esboço de uma teoria da prática de Pierre Bourdieu", Revista Crítica de Ciências Sociais, n. ${ }^{\circ}$ 64, pp. 135-143.

— $2002 d$, Formação e trabalho técnico-intelectual no associativismo florestal: análise de entrevistas com Engenheiros Florestais em Associações Florestais a Norte do Douro de Portugal. Porto, documento de trabalho REPROFOR, n. ${ }^{\circ} 5$ (policopiado).

— , 2003a, "As classificações “indígenas" sobre o trabalho técnico-intelectual: o caso de jovens engenheiros florestais no contexto de trabalho de associações florestais no norte de Portugal”. Comunicação apresentada no III seminário de investigação do DES-UTAD, Vila Real (policopiado).

—, 2003 b, "Os saberes do trabalho técnico-intelectual nas relações entre educação, trabalho e ciência". Texto de apresentação do painel sobre o mesmo tema organizado para o Midterm Conference Europe2003, RC 04. Lisboa, International Sociological Association (policopiado).

—, 2003 c, "A construção etnográfica do conhecimento em Ciências Sociais: reflexividade e fronteiras", in Experiência Etnográfica em Ciências Sociais. Porto, Afrontamento, pp. 9. -20 .

— 2004 a, "Os saberes profissionais técnico-intelectuais nas relações entre educação, trabalho e ciência”, em António Teodoro e Carlos Alberto Torres (orgs.), Educação Crítica \& Utopia: Perspectivas Emergentes para o Séc. XXI. Porto, Afrontamento, pp. 109-125.

— $2004 \mathrm{~b}$, “O conceito de prática em Bourdieu e a pesquisa em educação", Educação \& Realidade [Brasil], XXVIII(1), pp. 31-48.

— 2005 a, “Os saberes que fluem das profissões instituídas”. AA.VV. Actas do Ciclo de Conferências: Experiências Fluídas - Carreira e Precarização. Braga, Núcleo de Estudos em Sociologia do Instituto de Ciências Sociais da Universidade do Minho. 
CARIA, Telmo H., 2005b, Relatório final do projecto de investigação REPROFOR: síntese e análise auto-crítica. Centro de Investigação e Intervenção Educativas da Faculdade de Psicologia e Ciências da Educação da Universidade do Porto (policopiado).

—- No prelo, "Poder e reflexividade em ciência: revisão crítica do 'Science de la science' de Pierre Bourdieu". Revista Crítica de Ciências Sociais.

CARIA, Telmo H., e Ana Paula Vale, 1997, "O uso racionalizado da cultura. O caso da relação entre a consciência metafonológica e a aquisição da leitura”, Educação, Sociedade \& Culturas, n. ${ }^{\circ} 8$, pp. 45-72.

CASTELLS, Manuel, 2000 [1996], A Sociedade em Rede. Lisboa, Fundação Calouste Gulbenkian. CASTRO-CALDAS, Alexandre, e Alexandra Reis, 2000, "Neuropsicologia do analfabetismo", em Maria Raquel Delgado-Martins, Glória Ramalho, e Armanda Costa (orgs.), Literacia e Sociedade - Contribuições Pluridisciplinares. Lisboa, Caminho, pp. 155-184.

CHARLOT, Bernard, 2000 [1997], Da Relação com o Saber - Elementos para uma Teoria. Porto Alegre, Artmed.

COSTA, António Firmino da, 1999, Sociedade de Bairro. Oeira, Celta.

COUTURIER, Yves, 2002, "Les réflexivités de l'oeuvre théorique de Bourdieu: entre méthode et théorie de la pratique", Espirit Critique - Revue Electronique de Sociologie, IV, 3.

DAMÁSIO, António, 1994, O Erro de Descartes - Emoção, Razão e Cérebro Humano. Lisboa, Europa-América.

DELGADO-MARTINS, Maria Raquel, Ramalho, Glória e Armanda Costa, (orgs.), 2000, Literacia e Sociedade - Contribuições Pluridisciplinares. Lisboa, Caminho.

DUBAR, Claude, 1998, "A sociologia do trabalho frente à qualificação e à competencia", Educação e Sociedade, XIX, n. ${ }^{\circ} 64$.

—_, 1991, La Socialisation - Construction des Identités Sociales e Profissionelles. Paris, Armand Colin.

DUBET, François, 1996 [1994], Sociologia da Experiência. Lisboa, Instituto Piaget.

DUBREuIL, Bertrand, 2000, Imaginário Técnico e Ética Social. Lisboa, Instituto Piaget.

FILIPE, José, 2003a, Narrativas de Educadores em Centros de Actividades Ocupacionais. Porto, VI seminário ASPTI, documento de trabalho ASPTI, n. ${ }^{\circ} 22$ (policopiado).

—, $2003 \mathrm{~b}$, "Reflexividade interactiva e reflexividade institucional no desenvolvimento profissional de educadores e professores de educação especial". Comunicação apresentada no painel "Os saberes do trabalho técnico-intelectual nas relações educação, trabalho e ciência", em Midterm Conference Europe2003, RC 04. Lisboa, International Sociological Association (policopiado).

FRAWLEY, William, 1997, Vygostky and Cognitive Science. Cambridge, Massachusetts e Londres, Harvard University Press.

FRENAY, Mariane, 1996, "Le transfert des apprentissages", em Étienne Bourgeois (org.), L'Adulte en Formation. Bruxelas, Départtement de Boeck Université, pp. 37-58.

GIDDENS, Anthony, 1989, A Constituição da Sociedade. São Paulo, Martins Fontes.

—_, 1992, As Consequências da Modernização. Oeiras, Celta.

GOODY, Jack, 1987, A Lógica da Escrita e a Organização da Sociedade. Lisboa, Edições 70.

— 1988, A Domesticação do Pensamento Selvagem. Lisboa, Editorial Presença.

GONÇALVES, Maria Eduarda, 1993, Ciência e Democracia. Lisboa, Bertrand Editores.

HABERMAS, Jurgen, 1993 [1968], Técnica e Ciência como Ideologia. Lisboa, Edições 70.

INHelDer, Barbel, e Jean Piaget, 1976, Da Lógica da Criança à Lógica do Adolescente. São Paulo, Livraria Pioneira Editora. 
ITURRA, Raúl, 1988, “A construção conjuntural do grupo doméstico", Sociologia - Problemas e Práticas, n. ${ }^{\circ}$, pp. 61-78.

—_, 1990a, Fugirás à Escola para Trabalhar a Terra. Lisboa, Escher.

—

__, 1994, “O processo educativo: ensino ou aprendizagem”, Educação, Sociedade \& Culturas, n. ${ }^{\circ} 1$, pp. 29-50.

KARMILOFF-SMITH, Annette, 1995, Beyond Modularity. A Development Perspective on Cognitive Science. Massachusetts, Londress, The MIT Press.

LACASA, Pilar, e Pilar Herranz, 1989, "Contexto y procesos cognitivos - la interacción niñoadulto”, Infancia y Aprendizage, vol. 45, pp. 25-47.

LAHIRE, Bernard, 1993a, Culture Écrite et Inégalités Scolaires - Sociologie de l'Échec Scolaire à l'École Primaire. Lyon, Presses Universitaires de Lyon.

—_, 1993b, La Raison des Plus Faibles: Rapport au Travail, Écritures Domestiques et Lectures en Milieux Populaires. Lille, Presses Universitaires de Lille.

— 1998, L'Homme Pluriel - les Ressorts de l'Action. Paris, Nathan.

LASH, Scott, 2005, Crítica de la Informacion”. Buenos Aires-Madrid, Amorrortu Editores.

LAVE, Jean, 1991 [1988], La Cognición en la Prática. Barcelona, Paidós.

LAVE, Jean, e Seth Chaiklin, 1993, Understanding Pratice. Cambridge, Cambridge University Press.

MADUREIRA, C. Novais, e Carlos M. Rocha, 2002, "As diferentes faces da razão (II): risco, ciência e peritos", Revista Crítica de Ciências Sociais, n. ${ }^{\circ}$ 64, pp. 81-106.

NUNES, João Arriscado, 2000, "Públicos, mediações e construções situadas", em Maria Eduarda Gonçalves (org.), Cultura Científica e Participação Pública. Oeiras, Celta, pp. 81-100.

OLSON, David, 2002, The World on Paper: the Conceptual and Cognitive Implications of Writing and Reading. Cambridge, Cambridge University Press.

PEREIRA, Fernando, 2003, "O caso dos saberes dos técnicos superiores agrários das associações e cooperativas agrárias de Trás-os-Montes e Alto-Douro”. Comunicação apresentada no painel "Os saberes do trabalho técnico-intelectual nas relações educação, trabalho e ciência” em Midterm Conference Europe2003, RC 04. Lisboa, International Sociological Association (policopiado).

— 2005 , "Os saberes profissionais-técnicos em associações e cooperativas agrárias" em Saber Profissional. Coimbra, Almedina, pp.141-167.

PERRENOUD, Philippe, 1984, La Fabrication de lÉxcellence Scolaire. Genebra, Droz.

— , 1992, "Curriculum - le formel, le réel, le caché”, em J. Houssaye (org.), Pédagogie Savoirs Premiers. Paris, ESF.

—, 1994, Ofício de Aluno e Sentido do Trabalho Escolar. Porto, Porto editora.

— 2001 , Porquê Construir Competências a Partir da Escola? Porto, ASA.

PERRENOUD, Philippe, e Bernard Favre, 1989, "Organisation du curriculum et différenciation de e'enseignement”, em Eric Plaisance (org.), L'Échec Scolaire - Nouveaux Débats, Nouvelles Approaches Sociologiques. Paris, CNRS, pp. 55-73.

POZO, J. I., 1993, Teorias Cognitivas del Aprendizage. Madrid, Morata.

QUÉRÉ, Louis (org.), 1994, L'Enquete sur les Catégories - de Durkheim a Sacks. Paris, Éditions de l'École des Hautes Études en Sciences Sociales.

REY, Bernard, 1996, Les Compétences Transversales en Question. Paris, ESF éditeur.

ROGOFF, Barbara, 1993, Aprendices del Pensamiento - el Desarrollo Cognitivo en el Contexto Social. Barcelona, Paidós. 
SAHLINS, Marshall, 1980, Au Coeur des Societés - Raison Utilitaire et Raison Culturelle. Paris, Gallimard.

SCHON, Donald, 1998, El Professional Reflexivo: Como Piensan los Professionales Cuando Actúan. Barcelona, Paidós.

SILVA, Augusto Santos, 1994, Tempos Cruzados - um Estudo Interpretativo da Cultura Popular. Porto, Afrontamento.

STOER, Stephen, 1994, "Construindo a escola democrática através do campo da recontextualização pedagógica”, Educação, Sociedade \& Culturas, n. ${ }^{\circ}$ 1, pp. 7-28.

STOER, Stephen, e António Magalhães, no prelo, "Educação, conhecimento e sociedade em rede", Educação \& Sociedade.

SUN, Ron, 2002, Duality of Mind. A Bottom Up Approach Toward Cognition. Londres/Mahwah (Nona Jérsia), Lawrence Erlbaum Associates, Publishers.

TANGUY, Lucie, e Françoise Ropé (orgs.), 1994, Savoirs et Compétences. Paris, Harmattan.

TERSSAC, Gilbert de, 1998 [1996], “Savoir, compétences et travail”, em Jean-Marie Barbier (org.), Savoir Théorique et Savoirs d'Action. Paris, PUF, pp. 223-248.

TOCHON, François-Victor, 1998 [1996], “Grammaires de l'experience et savoirs-objects: le savoir focal dans la construction de nouveaux modéles de formation", em Jean-Marie Barbier (org.), Savoir Théorique et Savoirs d'Action. Paris, PUF, pp. 249-274.

VARELA, Francisco, Evan Thompson, Eleanor Rosch, 2003 [1991], A Mente Incorporada - Ciências Cognitivas e Experiência Humana. Porto Alegre, Artmed.

VENTURA, Paulo, Carlos Brito-Mendes, José Morais, e Régine Kolinsky, 2002, A Organização da Memória Semântica. Lisboa, Fundação Calouste Gulbenkian.

VIEIRA, Ricardo, 1999, Histórias de Vida e Identidades: Professores e Interculturalidades. Porto, Afrontamento.

VyGOTSKY, Lev, 1987, Pensamento e Linguagem. São Paulo, Martins Fontes.

vyGOTSKY, Lev, Alexander Luria, e Alexis Leontiev, 1988, Linguagem, Pensamento e Aprendizagem. São Paulo, Ícone.

WeRTSCH, J. V., 1988, Vigotsky y la Formation Social de la Mente. Barcelona, Paidós. 


\section{An itinerary of apprenticeship on the theoretical construction of knowledge as an object}

\section{Telmo H. Caria}

Departamento de Economia, Sociologia e Gestão da Universidade de Trás-os-Montes e Alto Douro. Centro de Investigação e Intervenção Educativas (CIIE) da Faculdade de Psicologia e Ciências da Educação da Universidade do Porto. Instituto de Ciências Sociais - Universidade de Lisboa

tcaria@utad.pt

The construction of theoretical research objects assumes the explicitation and rationalisation of the autobiographical trajectories that are inscribed in the professional culture of research in Social Sciences. These trajectories show that the relations between theory and data are not linear, as they are interspersed with cognitive conflicts. So there is a culture of problems in routine scientific practice that should not be confused with the rules and conflicts of legitimating the scientific output in a given social field. The autobiographical trajectory described takes the concepts of knowledge and professional culture as a core theoretical object. For this, a theoretical problem is developed that begins and ends in the question of socio-educational inequalities, and which has protractedly been contained in the interaction between the modalities of the contextual meaning of practical-contextual knowledge and in the professional recontextualisation of knowledge.

KEYWORDS: contextual meaning of knowledge, knowledge-information, professional recontextualisation of knowledge, mobilisation of knowledge, socio-educational inequalities. 